\title{
Physical-Mechanical Properties And Microstructure Of Breadfruit Starch Edible Films With Various Plasticizer
}

\author{
Cut Fatimah Zuhra Marpongahtun \\ Departemen Kimia FMIPA - USU Medan \\ E-mail: cfatimahzuhra@yahoo.com
}

\begin{abstract}
Breadfruit contains starch can be used as raw material of edible film. Research on preparation of edible films using various types of plasticizer (xylitol, sorbitol and PEG 400) has been done. The edible films were evaluated of physical-mechanical properties and microstructure. The results of this study indicate that the addition of plasticizer effect on the physical and mechanical characteristics, the edible film thickness, tensile strength and water vapor transmission rate greater using PEG 400 but percent elongation smaller than xylitol and sorbitol. Surface analysis of film was performed using Scanning Electron Microscopy (SEM) method.
\end{abstract}

Keyword : Edible Film; Pati Sukun; Plasticizer; Silitol; Sorbitol ; PEG 400

\begin{abstract}
ABSTRAK
Buah sukun mengandung pati yang dapat dimanfaatkan sebagai bahan baku edible film. Dalam penelitian ini telah dilakukan pembuatan edible film pati sukun menggunakan berbagai jenis plasticizer yaitu silitol, sorbitol dan PEG 400. Edible film yang diperoleh kemudian diuji sifat fisikmekanik dan mikrostrukturnya. Hasil dari penelitian ini menunjukkan bahwa penambahan jenis plasticizer berpengaruh terhadap karakteristik fisik dan mekanik edible film yaitu bahwa ketebalan, kuat tarik dan laju transmisi uap air edible film lebih besar menggunakan PEG 400 tetapi persen pemanjangannya lebih kecil bila dibandingkan silitol dan sorbitol. Uji morfologi permukaan terhadap edible film yang dilakukan dengan menggunakan Scanning Electron Microscopy (SEM).
\end{abstract}

Kata-kata kunci : edible film; Pati Sukun; Plasticizer; Silitol; Sorbitol ; PEG 400

\section{Pendahuluan}

Pengemasan merupakan suatu cara dalam memberikan kondisi sekeliling yang tepat bagi bahan pangan. Kerusakan yang terjadi mungkin saja spontan, tetapi ini sering disebabkan keadaan di luar dan kebanyakan pengemasan digunakan untuk membatasi antara bahan pangan dan keadaan normal sekelilingnya untuk menunda proses kerusakan dalam jangka waktu yang diinginkan. Faktor-faktor yang menyebabkan kerusakan pangan dapat dibagi menjadi dua golongan yaitu yang secara alamiah sudah ada dalam produk dan tidak dapat dicegah hanya dengan pengemasan saja, dan yang tergantung dari lingkungan sekitar dan mungkin dapat dikendalikan oleh pengemasan (Buckle et al., 1987).

Kemasan yang banyak digunakan adalah plastik yang berbahan dasar petrokimia, hal ini dikarenakan sifatnya yang praktis, kuat dan ekonomis, namun plastik 
sangat sukar terdegradasi. Plastik sintetik ini sangat berpotensi menjadi material yang membahayakan kelangsungan makhluk hidup di bumi ini. Untuk menyelamatkan lingkungan dari bahaya plastik sintetik, maka perlu dikembangkan penggunaan bahan alami yang mudah terdegradasi sebagai bahan utama penyusun kemasan.

Edible film merupakan alternatif sebagai bahan kemasan yang ramah lingkungan karena sifatnya yang biodegradable dan dapat dimakan sehingga tidak mencemari lingkungan. Walaupun tidak dimaksudkan untuk menggantikan secara total kemasan dari bahan sintetik, akan tetapi keunggulan dari edible film yaitu dapat dimakan, biokompatibilitas, tidak beracun, tidak menyebabkan polusi, memiliki sifat sebagai penghambat transfer massa (uap air, oksigen dan zat terlarut) dan harganya murah (Vasconez et al., 2009).

Komponen penyusun edible packaging mempengaruhi secara langsung bentuk morfologi maupun karakteristik pengemas yang dihasilkan. Edible film dapat dibuat dari bahan hidrokoloid dan lemak atau campuran keduanya. Beberapa hidrokoloid yang dapat dijadikan bahan pembuat edible film adalah karbohidrat (pati, alginat, pektin) dan protein (gelatin, kasein, gluten). Sedangkan lipid yang digunakan adalah lilin/wax dan asam lemak (Fennema, 1985).
Pati merupakan salah satu hidrokoloid yang biasa digunakan sebagai bahan dasar pembuatan edible film. Edible film yang dibuat dari hidrokoloid memiliki beberapa kelebihan, diantaranya baik untuk melindungi produk terhadap oksigen, karbondiooksida dan lipid, serta memiliki sifat mekanis sesuai dengan yang diinginkan. Sedangkan kekurangannya yaitu film dari pati kurang baik dalam hal barrier terhadap migrasi uap air (Doonhowe dan Fennema, 1994).

Buah sukun memiliki kandungan karbohidrat yang tinggi karena itu sukun merupakan salah satu sumber berharga untuk menghasilkan pati. Pati yang diperoleh dari sukun menghasilkan 18,5 g/100 g dengan kemurnian 98,86\% dan kandungan amilosa $27,68 \%$ dan amilopektin $72,32 \%$ (Rincom dan Fanny, 2004).

Edible film yang terbuat dari pati biasanya bersifat rapuh sehingga diperlukan penambahan plasticizer untuk mengubah sifat fisik dari film. Plasticizer adalah bahan non volatil, bertitik didih tinggi yang jika ditambahkan pada material lain dapat merubah sifat fisik material tersebut. Penambahan plasticizer dapat menurunkan ikatan hidrogen intermolekular antar polimer/kekuatan intermolekular (mengatasi sifat rapuh lapisan film), meningkatkan fleksibilitas film dan

Physical-Mechanical Properties And Microstructure Of Breadfruit ..................... 
menurunkan sifat-sifat penghalang film (Pranata et al., 2002 ).

\section{Tujuan Penelitian/Tujuan Penulisan}

Tujuan penelitian ini adalah untuk mengetahui pengaruh jenis plasticizer (sorbitol, silitol dan polietilen glikol 400) terhadap sifat fisik-mekanik dan mikrostruktur dari edible film pati sukun.

\section{Metode Penelitian/Penulisan}

\section{Alat dan Bahan}

Bahah yang digunakan adalah buah sukun, silitol, sorbitol, polietilen glikol 400 (PEG 400) dan aquadest. Alat yang digunakan Neraca analitik, alat-alat gelas, termometer, hot plate stirrer, Uji tarik dilakukan menggunakan alat uji tarik model MGF SC 2DE. Analisis morfologi permukaan menggunakan alat Scanning Electron Microscope (SEM) jenis JEOL JED 350.

\section{Prosedur Penelitian}

Larutan film dibuat dengan campuran pati sukun (5 g) dan silitol (1 g) dalam aquadest sebanyak $100 \mathrm{ml}$. Larutan tersebut kemudian dipanaskan pada suhu $85^{\circ} \mathrm{C}$ dan diaduk dengan menggunakan magnetik stirrer selama 45 menit. Larutan kemudian didinginkan dan dituang pada plat kaca dengan ukuran $20 \times 20$ $\mathrm{cm}$, dikeringkan dengan oven pada suhu $40^{\circ} \mathrm{C}$ selama 24 jam. Film berupa lapisan tipis yang terbentuk selanjutnya diuji sifat-sifat makaniknya berupa ketebalan, kuat tarik, persen pemanjangan, laju transmisi uap air dan uji morfologi permukaan edible film.

Dilakukan perlakukan yang sama untuk pembuatan edible film campuran pati sukun dan plasticizer lain yaitu sorbitol dan PEG 400.

\section{Hasil Dan Pembahasan}

Edible film pati sukun dibuat dengan menvariasikan jenis plasticizer yang digunakan yaitu silitol, sorbitol dan PEG 400. Edible film yang diperoleh kemudian di uji sifat mekanik, laju transmisi uap air dan morfologi permukaannya. Dari hasil penelitian dapat dilihat bahwa film yang terbentuk adalah transparan dari semua variasi jenis plasticizer, yang dapat dilihat pada Gambar 1 dibawah ini.
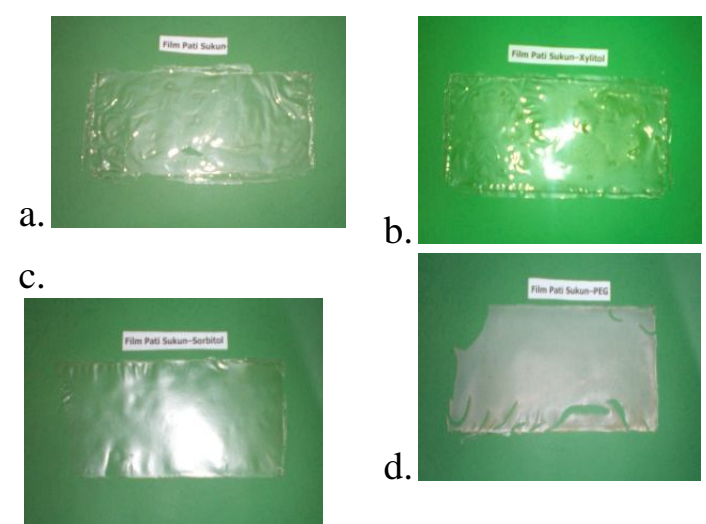

Gambar 1. Film pati sukun dengan variasi jenis plasticizer (a. Pati Sukun; b. Pati Sukun Silitol; c. Pati Sukun Sorbitol; d. Pati Sukun PEG 400)

Pengaruh Variasi Jenis Plasticizer (Silitol, Sorbitol, PEG 400) terhadap Sifak Fisik dan Mekanik dari Edible film Pati Sukun 
Salah satu tujuan ditambahkannya plasticizer didalam pembuatan film adalah untuk memperbaiki sifat fisik dan mekanik film. Sifat fisik dan mekanik yang dianalisis dalam penelitian ini adalah ketebalan film, kuat tarik dan persen pemanjangan.

Pengaruh dari perbedaan jenis plasticizer terhadap ketebalan edible film dapat dilihat pada Gambar 2, dimana menunjukkan bahwa ketebalan edible film yang menggunakan PEG 400 lebih besar bila dibandingkan dengan silitol dan sorbitol. Ketebalan edible film berkisar antara 0,041 $0,046 \mathrm{~mm}$.

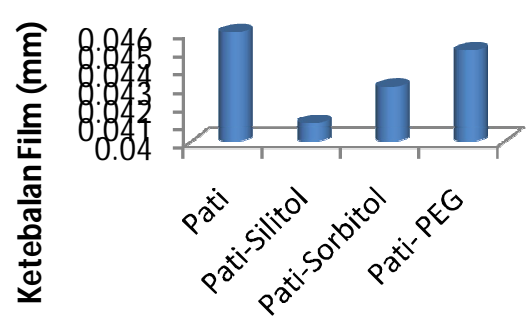

Gambar 2. Ketebalan edible film pati sukun untuk variasi jenis plasticizer

Dari hasil pengujian terhadap kuat tarik (Gambar 3) dan persen pemanjangan (Gambar 4) menunjukkan bahwa sifat mekanik sangat berpengaruh terhadap plasticizer yang digunakan.. Nilai kuat tarik yang diperoleh dari berbagai jenis plasticizer menunjukkan bahwa edible film yang ditambahkan dengan plasticizer PEG 400 memiliki kuat tarik yang lebih besar bila

Physical-Mechanical Properties And Microstructure Of Breadfruit ...................... ( Cut Fatimah Zuhra Marpongahtun) dibandingkan dengan silitol dan sorbitol. Kuat tarik dan efisiensi plasticizer tergantung pada berat molekulnya. Kuat tarik edible film akan meningkat dengan meningkatnya berat molekul (Laila, 2008). Oleh karena itu PEG 400 yang memiliki berat molekul lebih besar akan memberikan efek kuat tarik yang lebih besar tetapi akan menurunkan elastisitas dari film bila dibandingkan dengan silitol dan sorbitol.

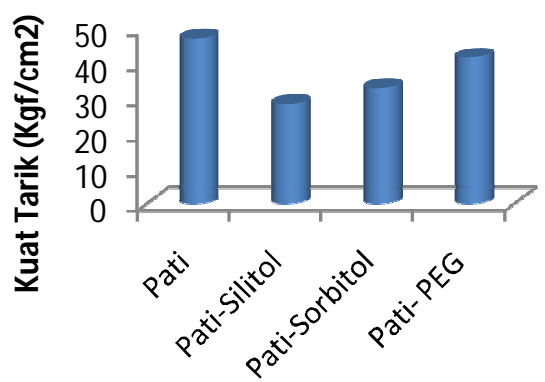

Gambar 3. Kuat tarik edible film pati sukun untuk variasi jenis plasticizer

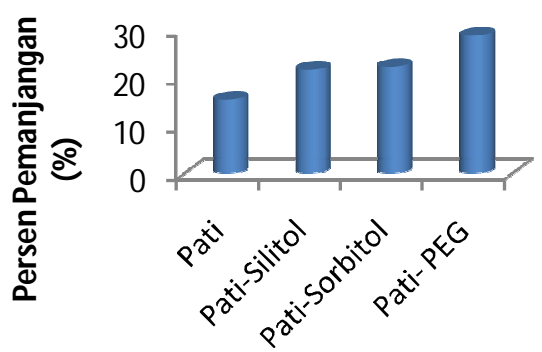

Gambar 4. Persen Pemanjangan edible film pati sukun untuk variasi jenis plasticizer

Plasticizer secara umum meningkatkan persen pemanjangan edible film 
higga konsentrasi tertentu. Plasticizer dapat mengurangi energi aktivasi untuk pergerakan molekul dalam matriks (Lukasik dan Ludescher, 2005).

Pengaruh Variasi Jenis Plasticizer (Silitol, Sorbitol, PEG 400) terhadap Laju Transmisi Uap Air dari Edible film Pati Sukun

Sifat penghalang film terhadap uap air dan gas ditunjukkan oleh koefisien permeabilitas yang semakin besar nilainya, dimana menunjukkan bahwa film tersebut semakin mudah dilewati oleh uap air dan gas (Lastriyanto et al., 2007).

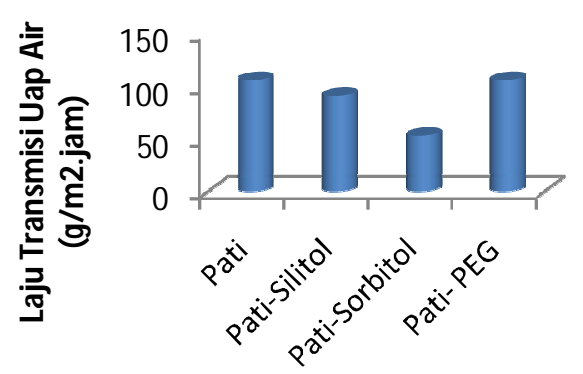

Gambar 5. Laju transmisi uap air edible film pati sukun untuk variasi jenis plasticizer

Pada laju transmisi uap air edible film hidrofilik, kelarutan air dan koefisien difusi meningkat ketika uap air meningkat karena afinitas kelembaban dari ediblle film dan pemberian zat plasticizer (Sothrovit dan Krochta, 2000). Laju transmisi uap air PEG 400 lebih besar bila dibandingkan dengan sorbitol dan silitol. Hal ini disebabkan karena PEG 400 memiliki ukuran molekul yang lebih besar dari silitol dan sorbitol sehingga akan memperbesar volume bebas antar rantai polimer sehingga mempermudah pemindahan molekul air (Donhowe dan Fennema, 1993; McHugh dan Krochta, 1994).

Pengaruh Variasi Jenis Plasticizer (Silitol, Sorbitol, PEG 400) terhadap Morfologi Permukaan dari Edible film Pati Sukun

Analisis SEM digunakan untuk

melihat karakteristik morfologi permukaan edible film. Gambar 6 merupakan hasil analisis edible film pati sukun dengan berbagai jenis plasticizer yaitu silitol, sorbitol dan PEG 400.

Karakteristik mikrostruktur film merupakan elemen yang penting dalam mengetahui sifat film. Foto mikrostruktur yang dihasilkan dengan menggunakan metode SEM bervariasi dari padat hingga renggang dan rata sampai bergelombang (Awwaly, et al., 2010).
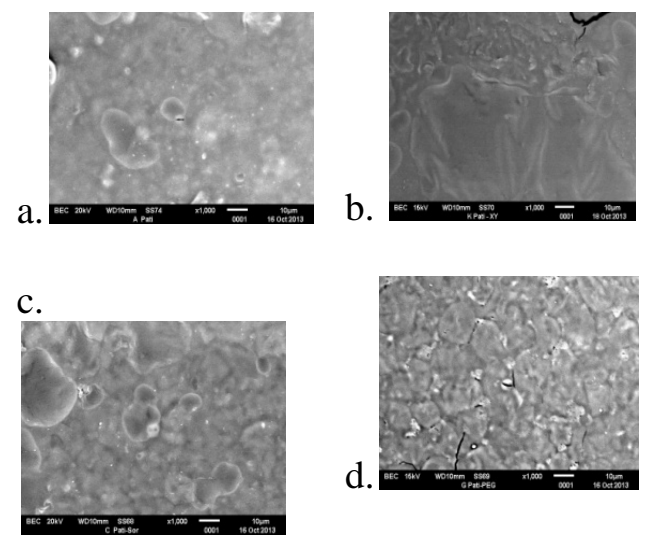

Gambar 6. Morfologi permukaan edible film pati sukun untuk variasi jenis plasticizer (a. Pati Sukun; b. Pati Sukun - Silitol; c. Pati Sukun - Sorbitol; d. Pati Sukun - PEG 400)

Untuk hasil analisis edible film pati sukun yang menggunakan PEG 400 yang terlihat pada Gambar 6 terlihat bahwa permukaan terlihat lebih kasar dan lebih padat dibandingkan dengan silitol dan sorbitol, hal 
ini karena PEG 400 memiliki ukuran molekul yang lebih besar yang menyebabkan penambahan jumlah total padatan edible film.

\section{Kesimpulan}

Berdasarkan dari hasil penelitian menunjukkan bahwa penambahan jenis plasticizer berpengaruh terhadap karakteristik fisik dan mekanik edible film yaitu bahwa ketebalan, kuat tarik dan laju transmisi uap air edible film lebih besar menggunakan PEG 400 tetapi persen pemanjangannya lebih kecil bila dibandingkan silitol dan sorbitol. Uji morfologi permukaan terhadap edible film yang dilakukan dengan menggunakan Scanning Electron Microscopy (SEM) menunjukkan perubahan pada sifat permukaan dan teksturnya.

\section{Ucapan Terima Kasih}

Penulis mengucapkan banyak terimakasih pada Ditjen Dikti Yang telah membiayai riset ini melalui dana BOPTN USU tahun anggaran 2013 dalam Program Hibah Fundamental. Dan kepada semua pihak yang telah membantu pelaksanaan penelitian ini.

\section{Daftar Pustaka}

Awwaly, K.U.Al., Manab, A. dan wahyuni, E. 2010. Pembuatan Edible Film Protein Whey: Kajian Rasio Protein dan Gliserol terhadap Sifat Fisik dan
Kimia. Jurnal Ilmu dan Teknologi hasil Ternak. 5. 45-56.

Buckle, K.A., Edwards, R.A., Fleet, G.H., Wootton, M. 1987, Ilmu Pangan, Penerjemah Hari Purnomo dan Adiono, UI Press, Jakarta..

Donhowe, G., Fennema, O., 1994, Edible Film and Coating: Characteristic, Formation, Definitions and Testing Methods, In: Krochta et al. (eds.). Edible Coating and Film to Improve Food Quality, Technomic Publ. Co. Inc. Lancaster, 378 pp.

Fennema, O.R., 1985, Food Chemistry. Marcell Dekker, Inc. New York. USA.

Laila, U, 2008, Pengaruh Plastiicizer dan Suhu Pengeringan terhadapp Sifat Mekanik Edible Film dari Kitosan. Laporan Penelitian Laboratorium Teknik pangan dan Bioproses, Jurusan Teknik Kimia, Fakultas Teknik. UGM.

Lastriyanto, A., Argo, B.D., Sumardi, H.S., Komar, N., Hawa, L.C., Hermanto, M.B., 200,. Penentuan Koefisien Permeabilitas Film Edibel terhadap Transmisi Uap Air, Gas $\mathrm{O}_{2}$, dan Gas $\mathrm{CO}_{2}$, Jurnal Teknologi Pertanian. 3, 179-183.

Lukasik. K.V., Ludescher. R.D., 2005. Effect of Plasticiizer on Dynamic site Heterogeneity in Cold-Cast Gelatin Films, J. Food Hydrocolloid. 20, 88-95.

Pranata, F.S., Djagal, W.M., Haryadi, 2002, Karakterisasi Sifat-Sifat Fisik dan Mekanik Edible Film Pati Batang Aren (Arenga pinnata Merr.), Biota 7, 121-130.

Rincom, A.M., Fanny, C.P., 2004, Physicochemical Properties of Venezuelan Breadfruit (Artocarpus 
altilis) Starch, Archivos Latinoamericanos De Nutricion, 53, 449-456.

Sothornvit, R., Krochta, J.M., 2000, Plasticizer Effect on Oxygen Permeability of $\beta$-lactoglobulin Film, $J$ of Agric and Food Chem. 48, 6298-6302.

Vasconez, M.B., Silvia, K.F., Carmen, A.C, Juan, A., Lia, N.G., 2009, Antimicrobial Activity And Physical Properties Of ChitosanTapioca Starch Based Edible Films And Coating. Food Research International, 42, 762-769. 